\title{
ACTIN-BASED VESICULAR TRANSPORT IN THE FIRST 20 MIN AFTER DUSK IS CRUCIAL FOR DAILY RHABDOM SYNTHESIS IN THE COMPOUND EYE OF THE GRAPSID CRAB HEMIGRAPSUS SANGUINEUS
}

\author{
ATSUKO MATSUSHITA AND KENTARO ARIKAWA* \\ Graduate School of Integrated Science, Yokohama City University, 22-2 Seto, Kanazawa-ku, Yokohama 236, Japan
}

Accepted 30 June 1997

\begin{abstract}
Summary
In the crab Hemigrapsus sanguineus, maintained under a $12 \mathrm{~h}: 12 \mathrm{~h}$ light:dark cycle, the amount of vesicular smooth endoplasmic reticulum (vesicular SER) in the photoreceptor cell body increases after the light is turned off. This paper demonstrates that actin filaments in the photoreceptor cell body are involved in the transport of vesicular SER towards the rhabdom. To specify the time of actin contribution to rhabdom synthesis, we disrupted the organization of actin filaments in the cell body with

from either $1 \mathrm{~h}$ before or immediately after extinguishing the light, the rhabdom size did not increase, whereas vesicular SER accumulated in the cell body. In contrast, cytochalasin D applied to the eyes from $20 \mathrm{~min}$ after turning the light off did not inhibit rhabdom synthesis. These results indicate that the first $20 \mathrm{~min}$ after the light is turned off is particularly important for the transport of vesicular sER towards the rhabdom by the cell body actin filaments.
\end{abstract} cytochalasin D at various time around dusk. We then measured the rhabdom size and also examined the ultrastructure of the photoreceptor cell body $3 \mathrm{~h}$ after extinguishing the light. When cytochalasin $D$ was applied

Key words: photoreceptor cell, cytoskeleton, invertebrate, vision, membrane cycle, actin, crab, Hemigrapsus sanguineus.

\section{Introduction}

The cytoskeleton plays a crucial role in establishing the polarity of cells. In the nervous system, for instance, microtubules are involved in the transport of cellular components between the cell body and the synaptic terminals in the squid giant axon (for a review, see Vale, 1987). Also, actin filaments are indispensable for the maintenance of cell polarity. Some evidence that actin filaments are involved in the motility of cell organelles is reported in Acanthamoeba sp. (Adams and Pollard, 1986) and in the giant axon of the squid Loligo pealeii (Kuznetsov et al. 1992; Bearer et al. 1996). Moreover, in locust (Schistocerca gregaria) photoreceptors, the actin filaments extending from the rhabdom, the photoreceptive organelle of the compound eye, are involved in the translocation of endoplasmic reticulum (ER) and mitochondria towards the rhabdom (Stürmer et al. 1995).

In this paper, we focus on the action of the actin filaments in crab photoreceptor cells, and specifically their role in the synthesis of the rhabdom. Crab photoreceptor cells are attractive for the study of the cellular mechanism underlying rhabdom synthesis because the rhabdom volume increases shortly after dusk (Nässel and Waterman, 1979; Stowe, 1980; Toh and Waterman, 1982; Arikawa et al. 1987; Toh, 1987).

In the grapsid crab Hemigrapsus sanguineus, we have shown that actin filaments are indispensable for the rhabdom synthesis that occurs around dusk (Matsushita and Arikawa, 1996). When actin filaments were disrupted by cytochalasin D (cytD) applied to isolated eyes immediately before light-off, rhabdom synthesis was inhibited, whereas vesicular smooth endoplasmic reticulum (sER) accumulated in the cell body. In contrast, cytD treatment started from $3.5 \mathrm{~h}$ after light-off had no effect on rhabdom volume (Matsushita and Arikawa, 1996). These results suggested the following. First, the accumulated vesicular sER is a precursor of the rhabdom membrane: in intact eyes, such vesicular sER increases in quantity during the late light period (Stowe, 1980; Arikawa et al. 1987; Toh, 1987). Second, the actin filaments in the cell body are involved in the transport of the precursors from the cell body towards the rhabdom in the first $3.5 \mathrm{~h}$ of the dark period.

However, we have frequently noticed that vesicular sER in the cell body is barely detectable in the eye $1 \mathrm{~h}$ after light-off. Thus, provided that the vesicular sER is the precursor of the rhabdom membrane, vigorous transport of the vesicular sER within the cell body most likely occurs within the first hour, not constantly for $3.5 \mathrm{~h}$, after light-off. Moreover, if the vesicular sER is indeed transported in an actin-dependent manner, the effect of actin disruption on rhabdom synthesis should be

\footnotetext{
*Author for correspondence (e-mail: arikawa@yokohama-cu.ac.jp).
} 


\section{A. Matsushita and K. AriKaWa}

restricted to at most the first hour after light-off. In the present study, we applied cytD to isolated eyes at the beginning of the increase in rhabdom volume in order to determine the period when, and also how, actin contributes to rhabdom synthesis.

Assuming that actin is involved in the transport of vesicular sER, one would expect some association between vesicular sER and actin filaments. There is a population of actin filaments that radiate from the rhabdom (Matsushita et al. 1991). Here, we present evidence, obtained by electron microscopic immunocytochemistry, that indicates a close association between vesicular sER and the radially oriented actin filaments.

\section{Materials and methods} Animals

Grapsid crabs Hemigrapsus sanguineus (de Haan) (carapace width $20-30 \mathrm{~mm}$ ) from rocky shores at Nojima Park, Yokohama City, Japan, were kept in a $12 \mathrm{~h}: 12 \mathrm{~h}$ L:D cycle (light $=04: 00-16: 00 \mathrm{~h}$, approximately $200 \mathrm{~lx}$ provided by a fluorescent tube) for at least 1 week at $25^{\circ} \mathrm{C}$ before the experiments.

\section{Organ culture}

The method of organ culture has been described previously (Matsushita and Arikawa, 1996). Briefly, the compound eyes were isolated from the eye stalk at the level of the basement membrane. The eyes were then incubated in $0.5-0.6 \mathrm{ml}$ of a medium (Blest et al. 1991) containing 1\% dimethylsulphoxide (DMSO) as a drug vehicle.

Fig. 1 shows the time schedule of isolation and incubation. We isolated eyes at different times (15:00, 16:05, 16:20 or $16: 45 \mathrm{~h}$ ) and then incubated them in cytochalasin-D-containing medium (cytD, $100 \mu \mathrm{moll}^{-1}$; Matsushita and Arikawa, 1996). All eyes were simultaneously fixed at 19:00 h (i.e. $3 \mathrm{~h}$ after light-off). Preparations made before light-off were carried out under room light; preparations made after light-off were carried out under dim red light.

\section{Tissue processing}

\section{Phalloidin labelling}

Eyes were fixed in $4 \%$ paraformaldehyde dissolved in 0.1 mol $^{-1}$ sodium phosphate buffer at $\mathrm{pH} 7.4(\mathrm{~PB})$ for $1 \mathrm{~h}$ at room temperature $\left(25-27^{\circ} \mathrm{C}\right)$. After immersion in $\mathrm{PB}$ for $1 \mathrm{~h}$, the eyes were infiltrated overnight in $30 \%$ sucrose in $\mathrm{PB}$ at $4{ }^{\circ} \mathrm{C}$. Cryosections $(6 \mu \mathrm{m}$ thick) were prepared and reacted with Rhodamine-conjugated phalloidin (1:50 in PB, Molecular Probes) overnight at $4{ }^{\circ} \mathrm{C}$. The sections were examined using a fluorescence microscope (Olympus, BX-60).

\section{Conventional electron microscopy}

Eyes were prefixed using a prefixative containing phalloidin (2\% paraformaldehyde, $2 \%$ glutaraldehyde, $1 \mathrm{mmoll}^{-1} \mathrm{MgCl}_{2}$, $1 \mathrm{mmoll}^{-1}$ EGTA, $10 \mu \mathrm{moll}^{-1}$ phalloidin and $0.2 \%$ saponin in $0.1 \mathrm{moll}^{-1}$ Pipes, $\mathrm{pH}$ 7.2) for $2 \mathrm{~h}$ at room temperature and further fixed in a fresh batch of the same prefixative overnight at $4{ }^{\circ} \mathrm{C}$. After washing with Pipes, the eyes were postfixed with

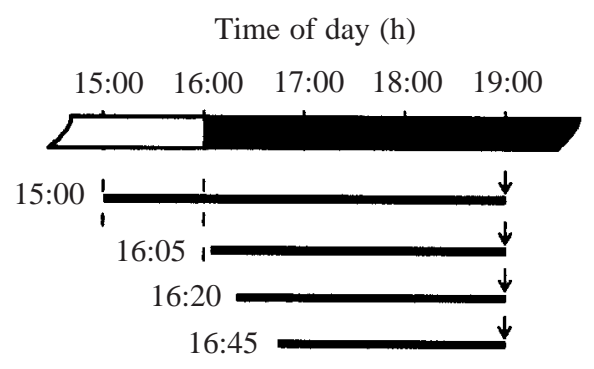

Fig. 1. Time schedule of the experiments. Numbers on the left side of each bar represent the time when incubation started (in h). Arrows indicate the sampling time for microscopy.

$2 \% \mathrm{OsO}_{4}$ in the same buffer for $2 \mathrm{~h}$ at room temperature, then dehydrated through an acetone series, infiltrated and embedded in Epon. Semi-thin sections were stained with Toluidine Blue. Ultrathin sections cut with a diamond knife were double-stained with uranyl acetate and lead citrate, and examined using a Jeol 1200EX electron microscope.

Rhabdom size was quantified as the area measured on light micrographs of transverse sections of ommatidia at the level close to the photoreceptor nuclei. The density of vesicular sER was measured on electron micrographs: we randomly selected two photoreceptor cells from each of four ommatidia for each individual and counted the number of sER vesicles per $\mu \mathrm{m}^{2}$ in a cell body.

\section{Electron microscopic immunocytochemistry}

Eyes were fixed with $4 \%$ paraformaldehyde, $0.5 \%$ glutaraldehyde and $4.5 \mathrm{mmoll}^{-1} \mathrm{CaCl}_{2}$ in $0.1 \mathrm{moll}^{-1}$ sodium cacodylate buffer $(\mathrm{CB}, \mathrm{pH} 7.3)$ for $1 \mathrm{~h}$ on ice, and then stored overnight in $\mathrm{CB}$ at $4{ }^{\circ} \mathrm{C}$. They were then postfixed with reduced osmium fixative containing $1 \% \mathrm{OsO}_{4}$ and $1.5 \%$ potassium ferrocyanide in $\mathrm{CB}$ for $30 \mathrm{~min}$ on ice (Tamaki and Yamashina, 1994). After being dehydrated through a graded methanol series, the eyes were embedded in LR White resin (London Resin Co.). Ultrathin sections were collected on nickel grids. The sections were first etched with saturated sodium metaperiodate for $3 \mathrm{~min}$, blocked with $4 \%$ bovine serum albumin (BSA) in $0.5 \mathrm{moll}^{-1}$ $\mathrm{NaCl}$ plus $0.25 \%$ gelatin in sodium phosphate buffer (PBSG, $\mathrm{pH} 7.4$ ) for $15 \mathrm{~min}$, and then incubated with monoclonal mouse IgM against chicken gizzard actin (final concentration $25-50 \mu \mathrm{g} \mathrm{ml}^{-1}$ in $1 \%$ BSA in PBSG, Amersham, code N. 350) overnight at $4{ }^{\circ} \mathrm{C}$. The anti-actin antibody was detected using goat anti-mouse IgM conjugated to gold particles ( $5 \mathrm{~nm}$ diameter, 1:50 in PBSG, Amersham) for $1 \mathrm{~h}$ at room temperature.

\section{Immunoblot analysis}

Retinal tissue was solubilized in Laemmli's sample buffer. Proteins were first separated by electrophoresis in a $10 \%$ SDS-polyacrylamide slab gel (Laemmli, 1970) and then electrophoretically blotted to a nitrocellulose sheet in a buffer containing $25 \mathrm{mmoll}^{-1}$ Tris, $192 \mathrm{mmoll}^{-1}$ glycine and $20 \%$ methanol. The blot was first blocked with $1 \%$ BSA in TBS $\left(150 \mathrm{mmol}^{-1} \mathrm{NaCl}\right.$ in $50 \mathrm{mmoll}^{-1}$ Tris- $\mathrm{HCl}$ buffer, $\left.\mathrm{pH} 7.4\right)$ 
for $20 \mathrm{~min}$, and then incubated with anti-actin antibody $\left(5 \mu \mathrm{g} \mathrm{ml}^{-1}\right)$ overnight at $4{ }^{\circ} \mathrm{C}$. The blot was incubated with biotinylated goat anti-mouse $\operatorname{IgG}$ and $\operatorname{IgM}(1: 2000$ in $1 \%$ BSA in TBS, Jackson) for $2 \mathrm{~h}$, and subsequently with horseradishperoxidase-conjugated avidin $\mathrm{D}\left(1 \mu \mathrm{ml}^{-1}\right.$ in $1 \% \mathrm{BSA}$ in TBS, Funakoshi) for $30 \mathrm{~min}$, which was then detected by the colour reaction with 4-chloro-1-naphthol.

\section{Results}

An ommatidium of the compound eye of $H$. sanguineus contains seven main photoreceptor cells (R1-R7). Their rhabdomeres form the major part of the rhabdom. The rhabdomere of the distal photoreceptor cell (R8) is situated at the tip of the rhabdom. The cell body of R1 is twice the size of the other six main photoreceptor cells (R2-R7) (Shaw and Stowe, 1982; Arikawa et al. 1987; Toh, 1990a). The ultrastructural observations reported here refer to the R2-R7 cells.

Our previous results indicate that cytD penetrates into the cell body and fragments the actin filaments, which appear as bright spots in the cell body. Even during the shortest incubation time (135 $\mathrm{min}$ ) in the present study, the drug could penetrate into the cell body (Matsushita and Arikawa, 1996). There appeared to be no other notable changes induced by cytD treatment in other cell organelles, such as the Golgi complex and rough ER.

\section{Rhabdom size}

The effect of cytD treatment on rhabdom size is shown in Fig. 2. Incubation was started at 15:00, 16:05, 16:20 or 16:45 h, and eyes were fixed for electron microscopy at 19:00 h

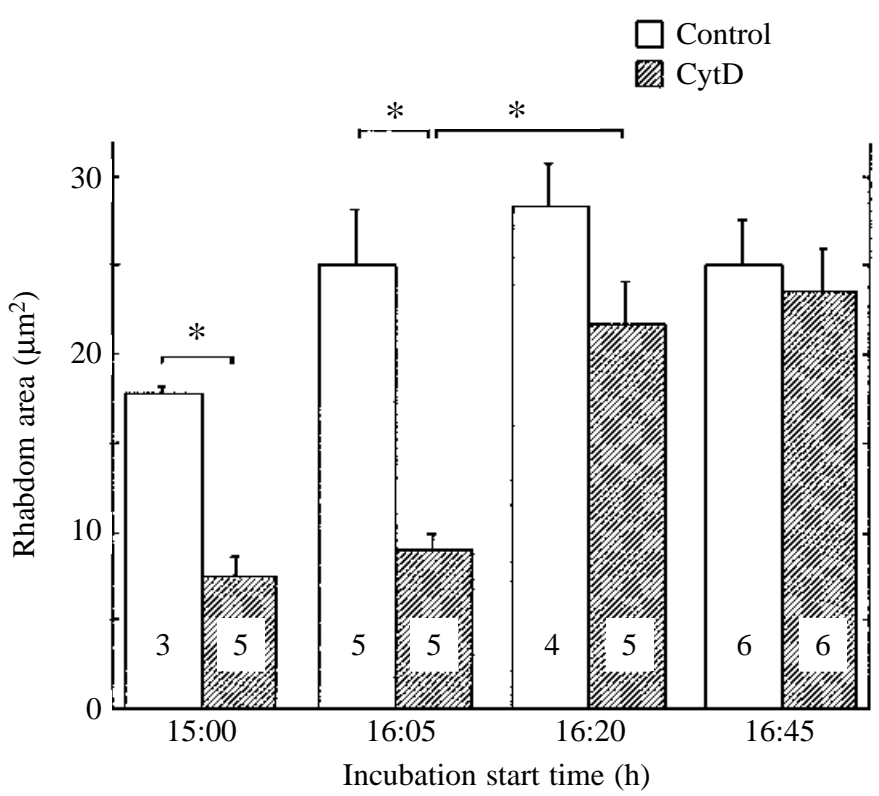

Fig. 2. Effects of $100 \mu \mathrm{moll}^{-1}$ cytochalasin D (cytD) on the rhabdom area (values are mean + S.E.M). Numbers in the column represent the number of individuals used $(N)$. The rhabdom areas were measured at the level of photoreceptor nuclei in 21-69 ommatidia from $N$ individuals for each treatment. *Significantly different; $P<0.01$ (Student's $t$-test). simultaneously. When the incubation was started at 15:00 or 16:05 $\mathrm{h}$, the rhabdom of the eyes incubated in cytD remained small, whereas the size of the rhabdom of control eyes increased significantly $(P<0.01, \quad$ Student's $t$-test $)$. The difference between the control and the cytD treatment was not significant when the incubation was started at $16: 20$ or $16: 45 \mathrm{~h}$.

\section{Density of vesicular SER}

In cytD-treated eyes, there was a tendency for vesicular sER to accumulate in the cell body in eyes treated from $15: 00 \mathrm{~h}$ or from 16:05 h (Figs 3, 4A,B), consistent with our previous results (Matsushita and Arikawa, 1996). The accumulated sER showed a vesicular profile even in longitudinal section; thus, these (sER) were apparently different from the large tubules of sER reported in the Leptograpsus variegatus photoreceptor cells (Stowe, 1980). In contrast, in the cytD-treated eyes incubated from either $16: 20$ or $16: 45 \mathrm{~h}$, the cell body contained only a few sER vesicles, as in the control (Figs 3, 4C,D): the densities of vesicular sER were significantly smaller than that found in eyes incubated from 16:05 $\mathrm{h}(P<0.01$, Fig. 3). In the cytD-treated eyes from 16:45 h (Fig. 4D), many small vesicles and a multivesicular body were observed in the cytoplasm immediately around the rhabdom. Such an abnormal localization of multivesicular bodies has been previously observed in crab photoreceptors after treatment with cytD for $6 \mathrm{~h}$ (Matsushita and Arikawa, 1996). The small vesicles and the vesicles in the multivesicular bodies are similar in diameter, implying the small vesicles are to be assembled to form a multivesicular body.

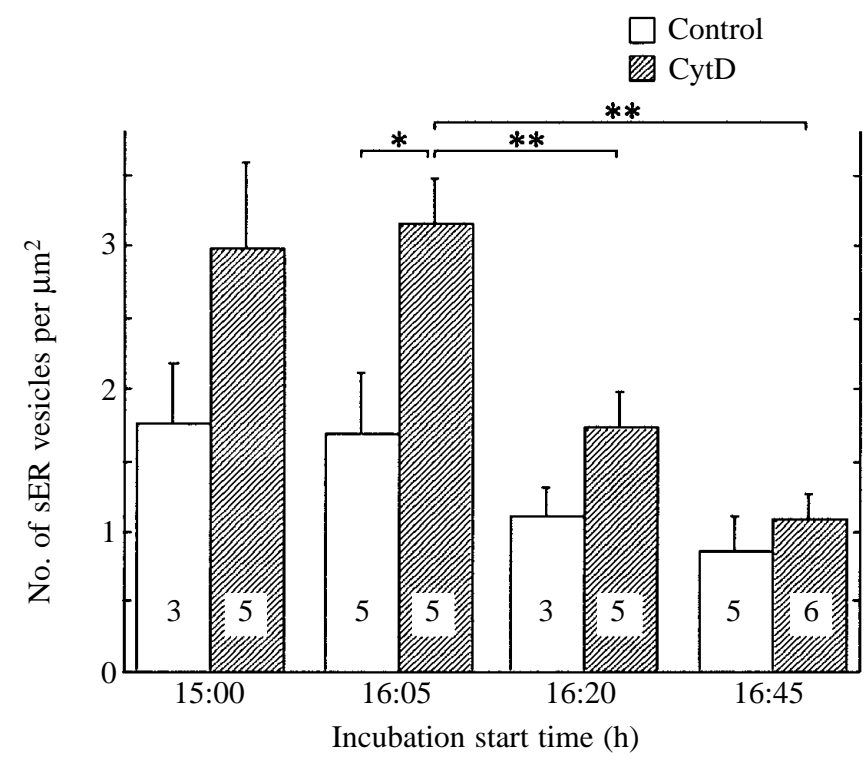

Fig. 3. Effects of $100 \mu \mathrm{moll}^{-1}$ cytochalasin D (cytD) on the number of smooth endoplasmic reticular (sER) vesicles per $\mu \mathrm{m}^{2}$ (values are mean + S.E.M.) in the cell body. Numbers in the column represent the number of individuals used $(N)$. Numbers of sER vesicles were counted in eight R2-R7 cells from four ommatidia for each individual. Asterisks denote significant differences: $\quad * P<0.05 ; \quad * * P<0.01$ (Student's $t$-test). 

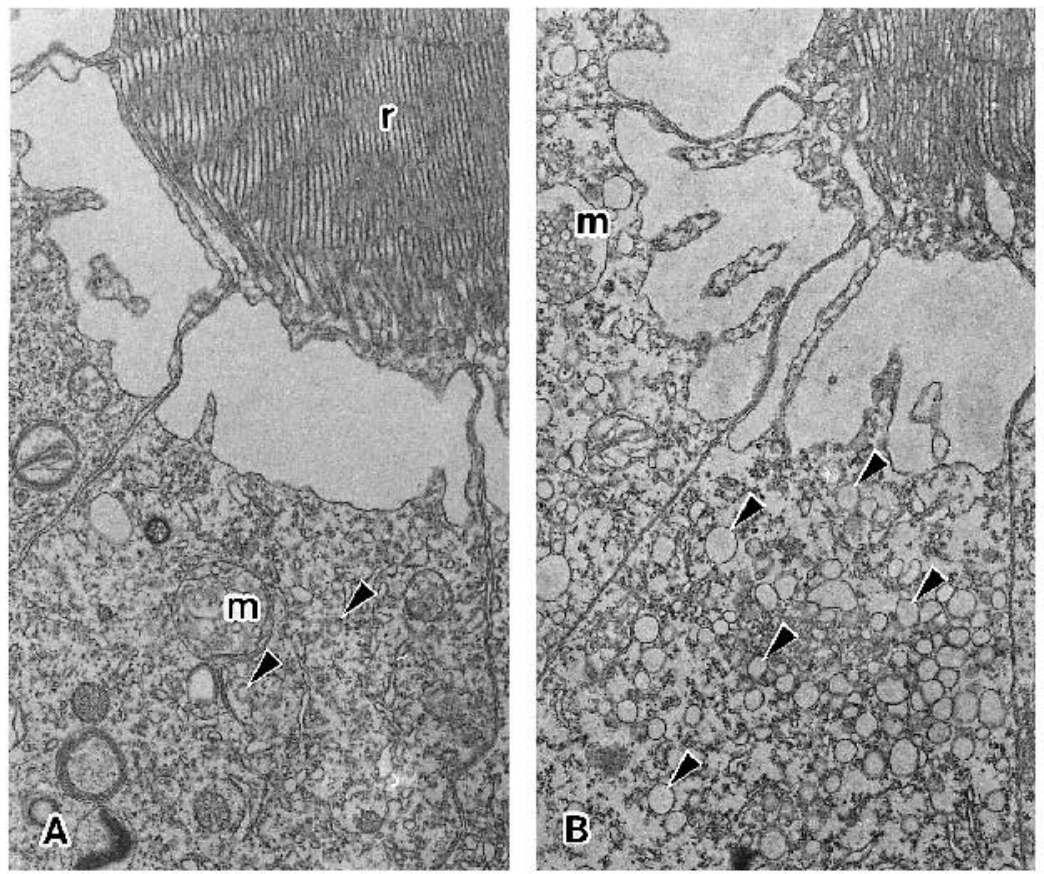

Fig. 4. Effects of cytochalasin D (cytD) on photoreceptor structure. Arrowheads indicate the vesicular smooth endoplasmic reticulum (sER) in the cell body. (A,B) Eyes incubated from $16: 05 \mathrm{~h}$ and sampled at 19:00 h. (A) Control; (B) treated with $100 \mu \mathrm{moll}^{-1}$ cytD. (C,D) Eyes incubated from 16:45 $\mathrm{h}$ and sampled at 19:00 $\mathrm{h}$. (C) Control; (D) treated with $100 \mu \mathrm{moll}^{-1} \mathrm{cytD}$. Small vesicles immediately around the rhabdom are evident in D (small arrows). r, rhabdom; m, multivesicular body. Scale bar, $1 \mu \mathrm{m}$.
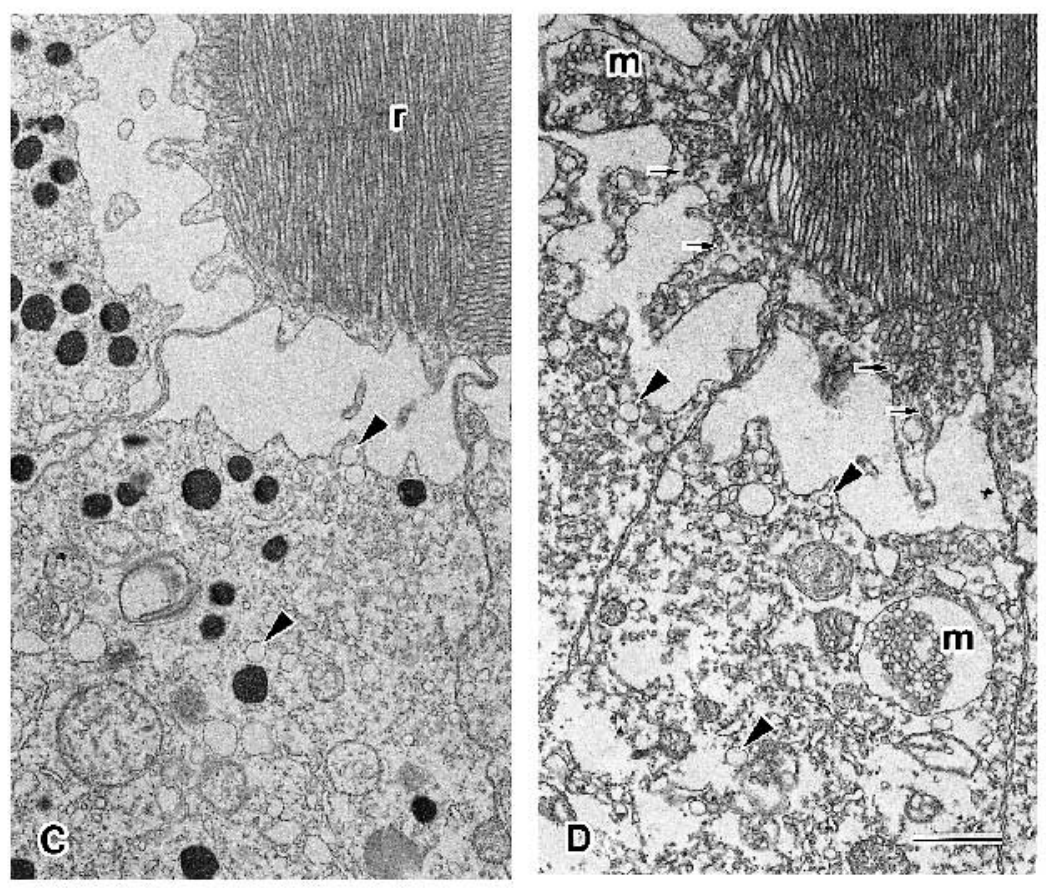

\section{Immunocytochemistry}

To reveal whether there is any association between the vesicular sER and actin filaments, we performed electron microscopic immunocytochemistry using anti-actin antibody. Vesicular sER appeared to be closely associated with a filamentous structure in the cell body (Fig. 5A). The filamentous structure immunoreacted with the antibody (Fig. 5B). The monospecificity of the anti-actin antibody was confirmed by blot analysis: the antibody detected only one band with a molecular mass of approximately $42 \mathrm{kDa}$ on a Western blot of retinal homogenate (Fig. 6).

\section{Discussion}

The present study demonstrates (1) that actin in the photoreceptor cell body is crucial for rhabdom synthesis during a period of at most 20 min after light-off, and (2) that actin is involved in the transport of vesicular sER towards the rhabdom.

When eyes were incubated with cytD from either 15:00 or 16:05 $\mathrm{h}$ until 19:00 h, the rhabdom area did not increase, indicating that the period when actin is involved in the increase in size of the rhabdom is somewhere between 16:05 and 19:00 h. By contrast, when eyes were incubated with cytD from 

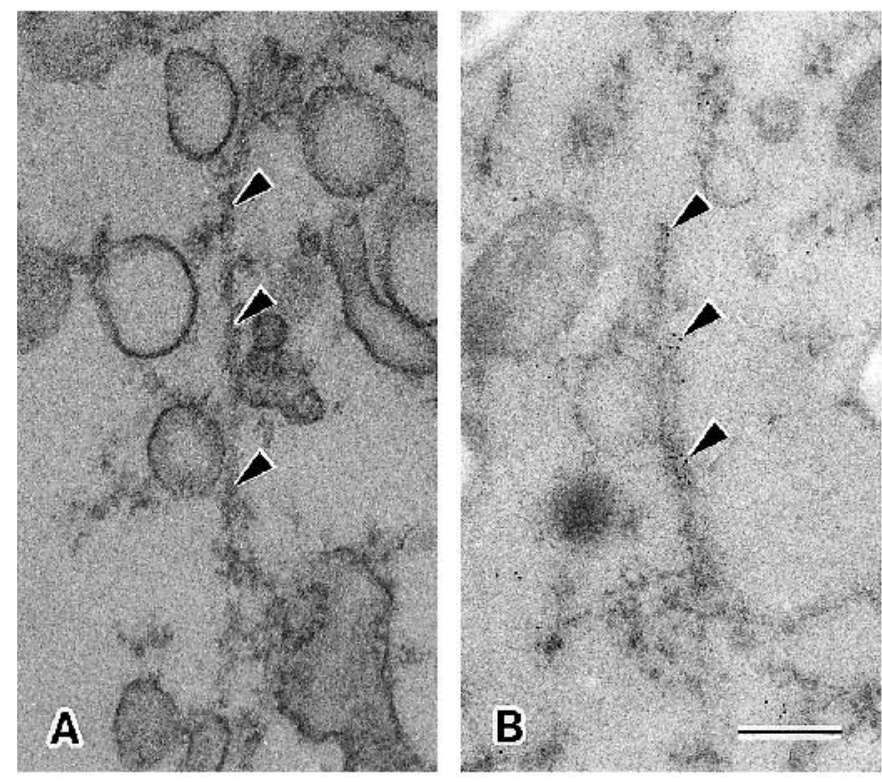

Fig. 5. Vesicular smooth endoplasmic reticulum (sER) associated with actin filaments. (A) Conventional electron micrograph. (B) Electron microscopic immunocytochemistry using anti-actin antibody, showing vesicular sER closely associated with an actin bundle (arrowheads). Scale bar, $0.2 \mu \mathrm{m}$.

either $16: 20$ or $16: 45 \mathrm{~h}$ until $19: 00 \mathrm{~h}$, the rhabdoms were synthesized even though actin organization had been disrupted by fragmenting the actin filaments (Matsushita and Arikawa, 1996). In other words, the organized actin system is not necessary for rhabdom synthesis between 16:20 and 19:00 h. In addition, vesicular sER accumulated only when rhabdom synthesis was inhibited: cytD treatment from $16: 05 \mathrm{~h}$ caused extensive accumulation of vesicular sER in the cell body, whereas treatment from 16:20 h did not. Taken together, we concluded that the critical period for actin to contribute to the rhabdom volume increase is from 16:05 to $16: 20 \mathrm{~h}$, i.e. up to 20 min after light-off.

It was reported in grapsid crabs that the rhabdoms were synthesized when the light was turned off during the day (Stowe, 1981; Arikawa et al. 1988). These results suggest (1) that the rhabdomeral membrane precursors are already prepared in the cell body during the light period (Stowe, 1980; Arikawa et al. 1987; Toh, 1990a), and (2) that the precursors do not move, or move to the vicinity of the rhabdom but are not incorporated into the rhabdomeral microvilli, until the light is turned off. Moreover, the vesicular sER has almost disappeared from the cell body within $45 \mathrm{~min}$ after light-off. Thus, it appears that, during the critical $20 \mathrm{~min}$ after light-off, vesicular sER is transported from the cell body towards the rhabdom, although the rhabdom volume continues to increase until 6h after light-off (Arikawa et al. 1987).

We still cannot exclude the possibility that vesicular sER is also transported before 16:05 h. Our preliminary results indicate that the amount of vesicular sER in the cell body starts to increase approximately $6 \mathrm{~h}$ before light-off and reaches a maximum approximately $1 \mathrm{~h}$ before light-off, and then

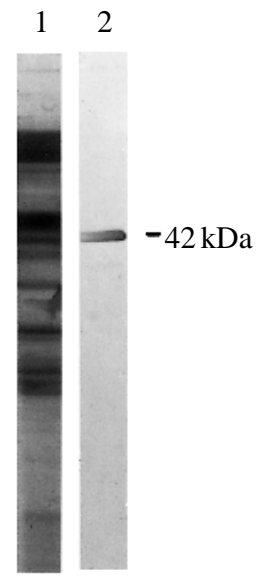

Fig. 6. Immunoblot analysis using anti-actin antibody. Electrophoretically separated retinal proteins were transblotted on a nitrocellulose sheet. Each lane contained a sample corresponding to 0.28 eyes. Lane 1, Coomassie-stained; lane 2, immunoblot incubated with anti-actin antibody.

decreases. This suggests that vesicular sER is transported to the rhabdom before light-off.

Since all eyes were simultaneously fixed at 19:00 h, the rhabdom size and the vesicular sER density in control experiments would ideally be the same irrespective of incubation time: the values should equal those of intact eyes fixed at 19:00 h. In fact, the rhabdom areas in control eyes incubated from either 16:20 or 16:45 $\mathrm{h}$ are close to those of the intact eyes (Arikawa et al. 1987). However, in the control eyes incubated from 15:00 h, the rhabdom area tended to be small (Fig. 2) and the density of vesicular sER tended to be high (Fig. 3) compared with other controls (no significant differences were detected). This is probably due to an artefact introduced by the prolonged incubation period (Eguchi et al. 1991), which somehow inhibited the incorporation of vesicular sER into the rhabdom. Alternatively, the absence of efferent input from the brain that controls the retinal structure (Chamberlain and Barlow, 1979), although such an input has not been demonstrated in grapsid crabs (Stowe, 1982; Eguchi et al. 1991; Matsushita and Arikawa, 1996).

We frequently observed vesicular sER attached to actin bundles in the photoreceptor cell body (Fig. 5). This is in line with the observation that cell organelles, such as vesicular sER, are transported along the actin filaments by the action of motor molecules, for example myosins (Adams and Pollard, 1986, 1989; Kuznetsov et al. 1992; Bearer et al. 1993, 1996; Fath and Burgess, 1993). Myosin-I-like ninaC proteins (NINACs) have been identified in photoreceptor cells of Drosophila melanogaster retina (Montell and Rubin, 1988). One of the NINAC isoforms, p174, is crucial for calmodulin transport into the rhabdomere by an interaction with actin filaments (Porter and Montell, 1993; Porter et al. 1993). We suggest that a NINAC-like motor protein also exists in crab photoreceptor cells, causing the transport of vesicular sER to its destination, the rhabdom. 
The structure of rhabdom precursors seems to be speciesspecific. In Palaemonetes pugio (Itaya, 1976), Leptograpsus variegatus (Stowe, 1980) and Callinectes sapidus (Toh, $1990 \mathrm{~b}$ ), the rhabdom precursors are large tubules of sER (for a review, see Blest, 1988). In contrast, as we have shown here, the precursors are more or less vesicular in $H$. sanguineus as well as in H. penicillatus (Toh, 1987, 1990a). The vesicular sER is transported from the cell body towards the rhabdom, where it is incorporated. The present results clearly indicate that the actin filaments in the cell body are involved in the transport process. Whether the contribution of actin to the process is a universal feature in rhabdomeral photoreceptors must await further studies in other species.

We thank Dr D. G. Stavenga and Dr E. Eguchi for critical reading of the manuscript. The work was supported by the grants from the Uehara Memorial Foundation and the Ministry of Education, Science and Culture of Japan to K.A.

\section{References}

Adams, R. J. AND Pollard, T. D. (1986). Propulsion of organelles isolated from Acanthamoeba along actin filaments by myosin-I. Nature 322, 754-756.

Adams, R. J. AND Pollard, T. D. (1989). Binding of myosin I to membrane lipids. Nature 340, 565-568.

Arikawa, K., Kawamata, K., Suzuki, T. and Eguchi, E. (1987). Daily changes of structure, function and rhodopsin content in the compound eye of the crab Hemigrapsus sanguineus. J. comp. Physiol. A 161, 161-174.

Arikawa, K., Morikawa, Y., Suzuki, T. and Eguchi, E. (1988). Intrinsic control of rhabdom size and rhodopsin content in the crab compound eye by a circadian biological clock. Experientia 44, 219-220.

Bearer, E. L., DeGiorgis, J. A., Bodner, R. A., Kao, A. W. And ReESE, T. S. (1993). Evidence for myosin motors on organelles in squid axoplasm. Proc. natn. Acad. Sci. U.S.A. 90, 11252-11256.

Bearer, E. L., DeGiorgis, J. A., Medeiros, N. A. And Reese, T. S. (1996). Actin-based motility of isolated axoplasmic organelles. Cell Motil. Cytoskel. 33, 106-114.

BLEST, A. D. (1988). The turnover of phototransductive membrane in compound eyes and ocelli. Adv. Insect Physiol. 20, 1-53.

Blest, A. D., Carter, M., Clausen, J. A., Stowe, S., Trowell, S. C. AND TsUKITANI, Y. (1991). Induction of retinal degeneration in a crab by light and okadaic acid in vitro: Comparison with the Drosophila light-dependent retinal degeneration mutant $w$ $r d g B^{K S 222}$. Vis. Neurosci. 7, 35-48.

Chamberlain, S. C. AND BARlow, R. B., JR (1979). Light and efferent activity control rhabdom turnover in Limulus photoreceptors. Science 206, 361-363.

Eguchi, E., Shimazaki, Y. And Suzuki, T. (1991). Changes in rhabdom volumes of isolated compound eyes of the crab, Hemigrapsus sanguineus - a study in correlation with a circadian rhythm. Zool. Sci. 8, 453-460.

FATH, K. R. AND BuRGESS, D. R. (1993). Golgi-derived vesicles from developing epithelial cells bind actin filaments and possess myosinI as a cytoplasmically oriented peripheral membrane protein. J. Cell Biol. 120, 117-127.
ITAYA, S. K. (1976). Rhabdom changes in the shrimp, Palaemonetes. Cell Tissue Res. 166, 265-273.

Kuznetsov, S. A., Langford, G. M. And Weiss, D. G. (1992). Actindependent organelle movement in squid axoplasm. Nature 356, 722-725.

LAEMMLI, U. K. (1970). Cleavage of structural proteins during the assembly of the head of bacteriophage T4. Nature 227, 680-685.

Matsushita, A. AND ArikawA, K. (1996). Disruption of actin filament organization by cytochalasin $\mathrm{D}$ inhibits rhabdom synthesis in the compound eye of the crab Hemigrapsus sanguineus. Cell Tissue Res. 286, 167-174.

Matsushita, A., AriKawa, K. And Eguchi, E. (1991). Distribution of F-actin in the compound eye of the crab, Hemigrapsus sanguineus. Zool. Sci. 8 (Suppl.), 1029.

Montell, C. And Rubin, G. M. (1988). The Drosophila ninaC locus encodes two photoreceptor cell specific proteins with domains homologous to protein kinases and the myosin heavy chain head. Cell 52, 757-772.

NÄSSEL, D. R. AND WATERMAn, T. H. (1979). Massive diurnally modulated photoreceptor membrane turnover in crab light and dark adaptation. J. comp. Physiol. A 131, 205-216.

Porter, J. A. AND Montell, C. (1993). Distinct roles of the Drosophila ninaC kinase and myosin domains revealed by systematic mutagenesis. J. Cell Biol. 122, 601-612.

Porter, J. A., Yu, M., Doberstein, S. K., Pollard, T. D. And Montell, C. (1993). Dependence of calmodulin localization in the retina on the NINAC unconventional myosin. Science 262, 1038-1042.

Shaw, S. R. AND Stowe, S. (1982). Photoreception. In The Biology of Crustacea, vol. 3 (ed. H. L. Atwood and D. C. Sandeman), pp. 291-367. New York, London: Academic Press.

Stowe, S. (1980). Rapid synthesis of photoreceptor membrane and assembly of new microvilli in a crab at dusk. Cell Tissue Res. 211, 419-440.

Stowe, S. (1981). Effects of illumination changes on rhabdom synthesis in a crab. J. comp. Physiol. A 142, 19-25.

STOWE, S. (1982). Rhabdom synthesis in isolated eyestalks and retinae of the crab Leptograpsus variegatus. J. comp. Physiol. A 148, 313-321.

StÜrmer, K., BaumanN, O. And Walz, B. (1995). Actin-dependent light-induced translocation of mitochondria and ER cisternae in the photoreceptor cells of the locust Schistocerca gregaria. J. Cell Sci. 108, 2273-2283.

TAMAKI, H. AND YAMASHINA, S. (1994). Improved method for postembedding cytochemistry using reduced osmium and LR White resin. J. Histochem. Cytochem. 42, 1285-1293.

ToH, Y. (1987). Diurnal changes of rhabdom structures in the compound eye of the grapsid crab, Hemigrapsus penicillatus. $J$. Electron Microsc. 36, 213-223.

ToH, Y. (1990a). Diurnal changes in the cytoplasmic organelles of the retinular cell in the compound eye of the grapsid crab, Hemigrapsus penicillatus. J. Electron Microsc. 39, 492-500.

ТоH, Y. (1990b). Diurnal structural changes in rhabdomeric microvilli of the compound eye in the blue crab, Callinectes sapidus. Zool. Sci. 7, 961-965.

ToH, Y. AND Waterman, T. H. (1982). Diurnal changes in compound eye fine structure in the blue crab Callinectes. I. Differences between noon and midnight retinas on an LD 11:13 cycle. $J$. Ultrastruct. Res. 78, 40-59.

VALE, R. D. (1987). Intracellular transport using microtubule-based motors. A. Rev. Cell Biol. 3, 347-378. 